\title{
Does foreign portfolio investment improve the economic growth of Jordan?
}

\author{
Huthaifa Al-karasneh ${ }^{a^{*}}$, Ashraf Bataineh ${ }^{a}$, Osama Hayajneh ${ }^{a}$ and Omar Khodirat ${ }^{a}$ \\ ${ }^{a}$ Department of Financial and Administrative Sciences, AL-Balqa Applied University/Irbid University College, Jordan

\begin{tabular}{l}
\hline C H R O N I C L E \\
\hline Article history: \\
Received: February 27, 2021 \\
Received in revised format: \\
April 29 2021 \\
Accepted: May 5, 2021 \\
Available online: \\
May 5, 2021 \\
\hline Keywords: \\
Economic Growth \\
Foreign Portfolio Investment \\
GDP \\
\hline
\end{tabular} \\ A B S T R A C T \\ This paper aims to examine the impact of short and long-term active Foreign Portfolio Investments \\ (FPI) on Jordan Economic Growth (EG) thru (1996-2017) by employing some econometric meth- \\ ods like ARDL and Error Correction Models to reach the study results. Findings reveal that FPI \\ have a long-term statistical positive impact on EG at level (5\%) and also have a short-term negative \\ impact on EG at level (5\%), where EG needs about ten years to reach a full adjustment. \\ (C) 2021 by the authors; licensee Growing Science, Canada
}

\section{Introduction}

The debt charges, public budget deficit, unemployment problems, sequenced crises, and the desire to open up to the outside world led Jordan; as one of the developing countries to try for the past three decades to support many efforts of selecting the optimal techniques to remove or decline difficulties by attracting edge-to-edge foreign and domestic investments, and then promoting the economic growth. The foreign investments contain two categories: foreign direct investment (FDI) and FPI, which develop and promote the financial markets and relate directly to the acceleration of countries' economic growth by covering the gap between savings and investments and using the foreign investments, especially portfolio investments. FPI is a grouped financial asset which include stocks, bonds, mutual funds, and cash equivalents that are privileged to high liquidity and very easy to convert into cash at any time. FPI gives many advantages to both foreign investors and the host countries, where foreign investors sometimes can benefit from buying securities at international financial markets which involve hedging their investments from risks by the diversification of portfolio and maximizing returns by utilizing differences of exchange rates. On the other side, the host country also can acquire some advantages from FPI such as adding new foreign currencies on its reserves to cover the deficits on balance of payments (Albulescu, 2015) and supplying the markets' capital with liquidity. It's worth noting that less developed countries are more interested in equity markets than debt markets because the equity tools deliver better gains and give better incentives to diversify global investment portfolios, which reduce risks to the lowest possible level (Agarwal, 1997). Foreign portfolios investors aim to own the securities, but without any control on the firm. In other words, foreign investors are relatively restricted to make the decision because their directions don't match with company's managers (Goldstein \& Razin, 2006). More specifically, investors focus on generating quick returns on their investments.

Study objectives can be summarized in the following:

1- Describe historical trends of Jordan FPI.

2- Assess the correlation between FPI and EG.

3- Explain short- and long-term correlation between FPI and EG.

* Corresponding author.

E-mail address: Huthaifa85@bau.edu.jo (H. Al-karasneh)

(C) 2021 by the authors; licensee Growing Science, Canada doi: $10.5267 /$ j.ac. 2021.5 .003 


\subsection{Trends of Foreign Portfolio Investment in Jordan}

When we talk about the portfolio investment, we have to mention the financial markets. Surely, Amman Financial Market considers an important tool that promotes the economy and a main channel to inflow the financial resources into Jordan, domestic and foreign investments alike.

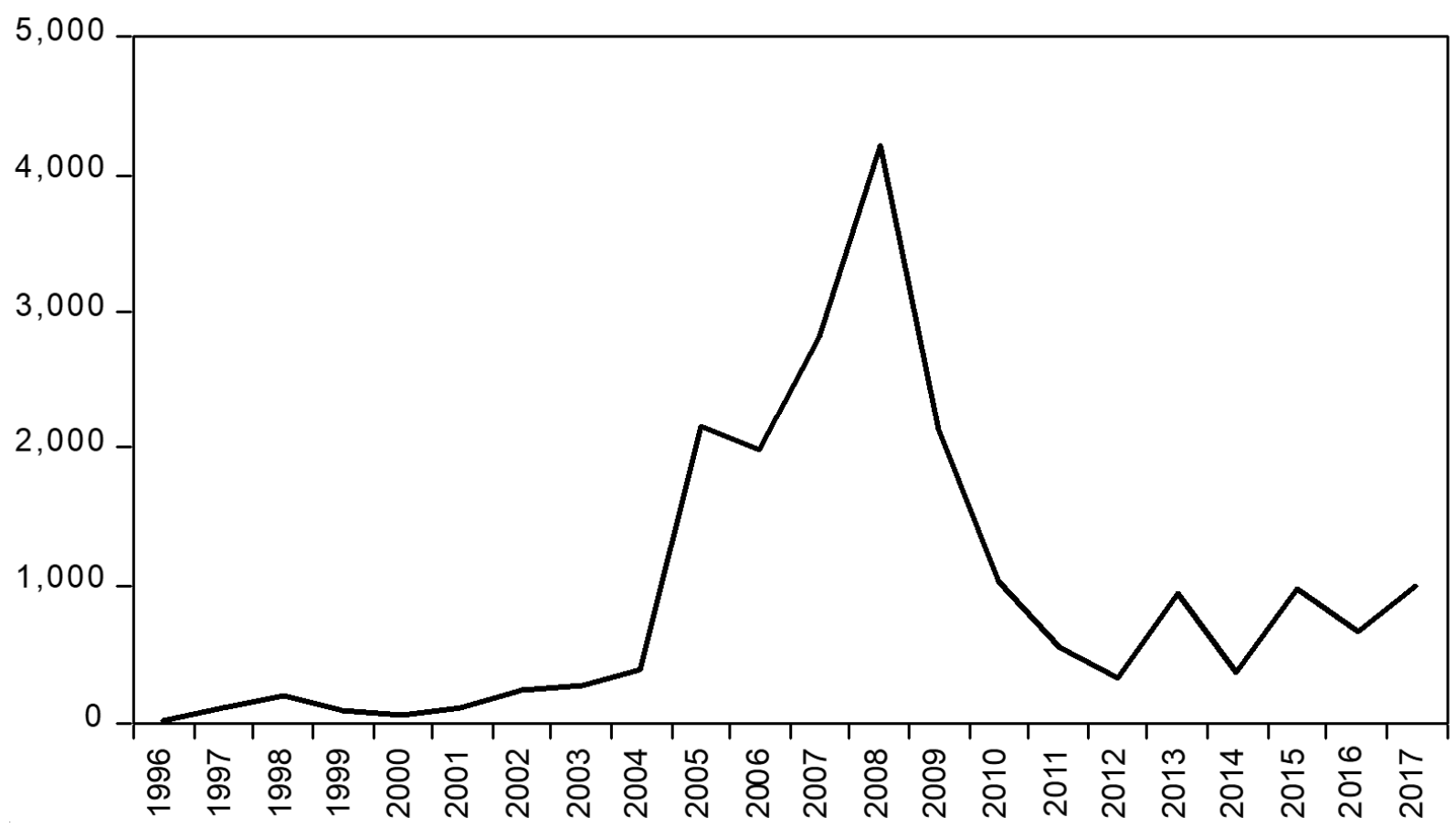

Fig. 1. Trend of foreign portfolio investment (Millions Jordan Dinars)

Fig. 1 shows the historical trends of FPI which contain three periods, the first one (1996-2004) reveals a slight and stable rise that ranged between 26 million dinars and 350 million dinars, due to the limited investments depth in terms of limited strong companies that represent the performance and liquidity, as well as limited investment tools are exchanging in Amman Financial Market based on trading of common stocks. Second period (2005-2008) showed a gradual and noticeable increase in FPI which reached its peak in 2008 with (4.2) billion dinars that constitute (27\%) of GDP. This may return to the desire of the government to attract foreign investments by improving the investment promotion law and developing the efficiency of financial market infrastructure, which reflects positively on the market value of stocks. Last period (2009-2017), the FPI decreased significantly between 2009 and 2012, as it declined from 4.2 billion dinars to 323 million and (92\%) were due to repercussions of the global financial crises. During this period, most foreign investors resorted to selling their investments and went toward safe investments and low risks, but during the period (2013-2017) FPI began to fluctuate up and down.

\section{Literature review}

The examination of previous research showed only few studies related to the relationship between FPI and EG. Duasa and Kassim (2009) used Granger Causality and Toda Yamamoto Non-Causality Tests to study the connection between FPI and Malaysia's Economic Performance for the period (1991-2006). Results indicated no connection between FPI and the Economic Performance but indicated that EG considers a main factor to attract FPI. Baghebo and Apere (2014) gave evidence of FPI impact on the long-term Nigerian EG during (1986-2011) by employing Augmented Dickey Fuller Test, Johansen Cointegration Technique, and Errors Correction Mechanisms. Results showed a long-term positive correlation of FPI, Market Capitalization, and Open Trade with the real EG or GDP of Nigeria. The study of Durham (2003) aimed to examine foreign investments' impact on EG on a sample of (88) states during (1977-2000), and showed no impact of FPI on EG. Study of Ahmad et al. (2016) aimed to identify causality relationship between FPI and EG among ASEAN5 during (2001-2013). Researchers used Granger Causality and Wald test, and experimental analysis only showed a correlation between FPI and EG in Singapore. Sethi (2007) aimed to investigate the effect of global investment movements on EG of India through Time Series Method during (April 1995-April 2007). Researchers used various analysis techniques, such as Dickey-Fuller and Philip Pearson Tests and indicated a positive effect of FPI on EG. The study of Baharumshah et al. (2015) found an indication of three types of foreign capital impact, which include FDI, foreign equity portfolio, and debt inflows on the economic growth. Researchers reached two main results by implementing the threshold analysis method and found strong evidence on a non- 
linear relationship between the private PFI and EG, while capital investments give positive advantages, especially in development countries. Sawalha, et al. (2016) aimed to test the impact of FDI and FPI on EG of Developed and Developing Countries during (1980-2012). Study results showed a negative effect of FPI on EG of both Countries.

\section{Data and methodology}

\subsection{Data}

The study covered the period (1996-2017) which depends on data of annual time series that represent the economic growth proxy of GDP; at current prices acquired from annual reports of Jordan Central Bank, which measured by the logarithm of GDP. The FBI extracted from annual reports issued by Amman Stock Exchange and relied on purchasing stocks of foreign investors to inflow the funds to capital market, which measured by the logarithm of FPI while the study uses Consumer Price Index (CPI) as a controlled variable measured by logarithm of CPI drown from reports issued by the Jordan Central Bank.

\subsection{Methodology}

The study model used to show FPI impact on Jordan's EG by depending on the Production Function Method of Cobb-Douglas (1928), as formulated in the following formulas:

$$
G D P: f(L, K)
$$

GDP: Gross Domestic Products

\section{$L$ : Total Labor Force}

$K$ : Capital

Production function can be modified to align with the study variables

$$
\log G D P=f(\log F P I, \log C P)
$$

where

Log GDP: Logarithm of Gross Domestic Products

Log FPI: Logarithm of Foreign Portfolio Investments

Log CPI: Logarithm of Consumer Price Index

To calculate FPI effect on Jordan's EG, some steps must be implemented before reaching the expected results of this study which are as follow:

Step 1: Perform stationary tests of study Time Series by using unit root test, where it should be known the existence of more than one test to identify Time Series Stationary. In this study, researchers will conduct two types of test which are: DickeyFuller (GLS) test (Elliott et al., 1990) and Philips-Perron (PP) test by Philips \& Perron (1988).

Step 2: Lag the length selection criteria by finding the lag length optimum number of models based on five criteria (LR, FPE, AIC, SC \& HQ).

Step 3: Conduct co-integration tests to analyze the non-stationary time series that suffer from deviations and its average which vary over time and used to evaluate the long run stability in the model with unit root variables. In this step, we use Johansen cointegration test (Johansen, 1991) which includes Trace Test and Maximum Eigenvalue Test.

Step 4: Use Granger Causality Test (Granger, 1969) as a statistical concept to predict how one series is useful to forecast another, one variable does cause another variable, or bi-directional or unidirectional causality relationship. In this step we use the following models to estimate Granger Causality results.

$$
\begin{aligned}
& \log G D P_{t}=\alpha_{0}+\sum_{t=1}^{k} \alpha_{i} \log G D P_{t-i}+\sum_{j=1}^{k} \beta_{j} \log F P I_{t-j}+\sum_{m=1}^{k} \delta_{m} \log C P_{t-m}+e_{t} \\
& \log F P I_{t}=\alpha_{0}+\sum_{t=1}^{k} \alpha_{i} \log G D P_{t-i}+\sum_{j=1}^{k} \beta_{j} \log F P I_{t-j}+\sum_{m=1}^{k} \delta_{m} \log C P_{t-m}+u_{t} \\
& \log C P_{t}=\alpha_{0}+\sum_{t=1}^{k} \alpha_{i} \log G D P_{t-i}+\sum_{j=1}^{k} \beta_{j} \log F P I_{t-j}+\sum_{m=1}^{k} \delta_{m} \log C P_{t-m}+\varepsilon_{t}
\end{aligned}
$$


Step 5: Conduct ARDL test has more advantages than Johansen cointegration test because ARDL is appropriate regardless of whether variables have the same rank as opposed to Johansen test which requires their merger with the same rank, and it can at the same time estimate the model parameters; on the short and long-term simple modification. ARDL Model on long-term which shows the independent variables (FPI \& CPI) effect on the dependent variable (EG) may be calculated according to the following equation:

$$
\log G D P_{t}=\alpha_{0}+\sum_{i=1}^{m} \alpha_{1 i} \log G D P_{t-i}+\sum_{i=0}^{n} \alpha_{2 i} \log F P I_{t-i}+\sum_{i=0}^{p} \alpha_{3 i} \log C P_{t-i}+\omega_{1 t}
$$

While ECM which branched from ARDL Bounds Test shows the short-term effect, as expressed in the following formula:

$$
\operatorname{DlogGDP}_{\mathrm{t}}=\alpha_{0}+\sum_{\mathrm{i}=1}^{\mathrm{m}} \alpha_{1 \mathrm{i}} \operatorname{DlogGDP}_{\mathrm{t}-\mathrm{i}}+\sum_{\mathrm{i}=0}^{\mathrm{n}} \alpha_{2 \mathrm{i}} \mathrm{DlogFPI}_{\mathrm{t}-\mathrm{i}}+\sum_{\mathrm{i}=0}^{\mathrm{p}} \alpha_{3 \mathrm{i}} \operatorname{DlogCP}_{\mathrm{t}-\mathrm{i}}+\varphi \operatorname{Coint} E q_{t-i}+\omega_{1 \mathrm{t}}
$$

Last step investigates short and long-term structural stability of study variables' parameters (Pesaran \& Pesaran, 1997) by relying on two tests: CUSUM and CUSUMSQ. Structural Reliability of parameters occurs when plots of CUSUM and CUSUMSQ come together at (5\%) of critical lines, while it considers instable if CUSUM and CUSUMSQ plots go outside the critical lines zone (Brown, Durbin \& Evans, 1975; Garg \& Dua, 2014).

\section{Empirical analysis}

\subsection{Unit root test}

Table 1 shows results of Unit-Root Test, where Log GDP is stationary and integrated at level according to DF-GLS test, whereas it's stationary and integrated at first difference based on PP test. Log FPI and log CP are stationary and integrated at first difference in both tests, which means that all variables are stationary on the long run.

Table 1

Unit-Root Test Results

\begin{tabular}{lcccc}
\hline \multicolumn{2}{c}{ Variables } & DF-GLS & \multicolumn{2}{c}{ PP } \\
\hline Log GDP & Level & First Difference & Level & First Difference \\
Log FPI & $-3.341391^{* *}$ & -1.229611 & Decision I $(0)$ & $-2.952264^{*}$ \\
Log CP & 1.615341 & $-4.853229^{* * *}$ & -2.278606 & $-4.842296^{* * *}$ \\
\hline Sour: & -1.592725 & $-4.137767^{* * *}$ & -0.196029 & $-4.058180^{* * *}$ \\
\hline
\end{tabular}

Source: Authors calculation using E-Views 10

\subsection{Lag Length Selection}

Researchers must define the Optimal Lag Length before performing Co-Integration and Granger Causality Tests, where table (2) shows criteria used to determine Lag Length. Tests discovered that two criteria (LR \& SC) identified Lag 1; FPE criterion has Lag 2 while (AIC \& HQ) have Lag 3. In this case, we take lower Lag which is Lag 1.

\subsection{Co-Integration Test}

The test used for investigating acceptable economic relationship at long-run stability between Non-Stationary Time Series, where table (3) shows the Cointegration test results. It's clear from the extracted results that calculated values for both Trace and Max-Eigen statistics are larger than significant value level of $(5 \%)$ which indicates an existence of one Co-Integration equation, because the null hypothesis has been rejected.

Table 2

\begin{tabular}{|c|c|c|c|c|c|c|}
\hline Lag & $\log \mathrm{L}$ & LR & FPE & AIC & $\mathrm{SC}$ & HQ \\
\hline 0 & 56.71696 & NA & $5.14 \mathrm{e}-07$ & -5.968551 & -5.820156 & -5.948090 \\
\hline 1 & 124.6881 & $105.7329^{*}$ & $7.49 \mathrm{e}-10$ & -12.52090 & $-11.92732^{*}$ & -12.43905 \\
\hline 2 & 134.5808 & 12.09109 & $7.55 e-10$ & -12.62009 & -11.58132 & -12.47686 \\
\hline 3 & 147.6471 & 11.61453 & $6.46 \mathrm{e}-10^{*}$ & -13.07190 & -11.58795 & -12.86729 \\
\hline 4 & 159.9685 & 6.845193 & $9.13 e-10$ & $-13.44094 *$ & -11.51180 & $-13.17494 *$ \\
\hline
\end{tabular}

Results of Lag Length Selection

Source: Authors calculation using E-Views 10

Table 3

\begin{tabular}{|c|c|c|c|c|}
\hline $\begin{array}{l}\text { Hypothesized } \\
\text { No. of CE(s) }\end{array}$ & Eigen-Value & $\begin{array}{c}\text { Trace } \\
\text { Statistic }\end{array}$ & $\begin{array}{c}0.05 \\
\text { Critical-Value } \\
\end{array}$ & Prob.** \\
\hline None ${ }^{*}$ & 0.837129 & 51.19380 & 29.79707 & 0.0001 \\
\hline At most 1 & 0.474492 & 14.89786 & 15.49471 & 0.0613 \\
\hline At most 2 & 0.096522 & 2.030065 & 3.841466 & 0.1542 \\
\hline $\begin{array}{l}\text { Hypothesized } \\
\text { No. of CE(s) }\end{array}$ & Eigen-Value & $\begin{array}{c}\text { Trace } \\
\text { Statistic }\end{array}$ & $\begin{array}{c}0.05 \\
\text { Critical-Value }\end{array}$ & Prob.** \\
\hline None* & 0.837129 & 36.29594 & 21.13162 & 0.0002 \\
\hline At most 1 & 0.474492 & 12.86779 & 14.26460 & 0.0821 \\
\hline At most 2 & 0.096522 & 2.030065 & 3.841466 & 0.1542 \\
\hline
\end{tabular}

Results of Co-Integration Test 
Based on statistical models (3, 4 \& 5), Table 4 shows the casual relationship among the variables with each other. Study results conclude that FPI had a direct significance impact on economic growth or GDP at level (1\%) but found non-existence of causal correlation between EG or GDP and FPI. Results also conclude the existence of Uni-Directional Correlation between FPI and EG or GDP. In regard to the Causal Correlation between EG or GDP and FPI from one side and the CPI from the other side, study indicated a Bi-Directional Causal Correlation between EG or GDP and CPI, and also indicated a Unidirectional Causal Significance Correlation between FPI and CPI at level (5\%).

\section{Table 4}

Results of Granger Causality Test

\begin{tabular}{lccc}
\hline Null Hypothesis & Obs & F-Statistic & Prob. \\
\hline F doesn't Granger Cause G & 21 & 18.8834 & 0.0004 \\
G doesn't Granger Cause F & & 0.00039 & 11.1976 \\
P doesn't Granger Cause G & 21 & 14.0593 & 0.9844 \\
G doesn't Granger Cause P & & 0.00928 & 0.0036 \\
P doesn't Granger Cause F & 21 & 4.68745 & 0.0015 \\
F doesn't Granger Cause P & & 0.9243 & 0.0441 \\
\hline
\end{tabular}

Source: Authors calculation with using E-Views 10

\subsection{ARDL Estimation Results}

Study aims to identify FPI impact on EG during (1996-2017), where it's essential to identify short and long-term effects of this relationship. Long-term analysis illustrated in Table 5, which estimated according to model (6) and results indicate the existence of FPI positive impact on EG at level (5\%), which means (1\%) growth in foreign portfolio will cause an enhancement of EG or GDP by (1.42\%), at Lag 1 in the long-term and this agree with (Baghebo \& Apere, 2014) study results.

Table 5

Log-Term Estimates

\begin{tabular}{lccc}
\hline Variables & Coefficient & Std. Error & T-Statistic \\
\hline G(-1) & 0.733596 & 0.115028 & 6.377546 \\
F & 0.015644 & 0.005678 & 2.755369 \\
F(-1) & 0.014241 & 0.005178 & 2.750154 \\
P & 1.226696 & 0.163696 & 0.0000 \\
P(-1) & -0.614611 & 0.263818 & 0.0147 \\
C & 1.260010 & 0.551917 & 0.0000 \\
\hline Source: Authors calculation with using E-Views 10 & & 0.0342 & 2.329675 \\
\end{tabular}

Source: Authors calculation with using E-Views 10

The short run coefficients obtained from model (7) are displayed in Table 6, where FPI has statistically significance negative correlation with economic growth or GDP at level (5\%) which means that if FPI increases by (1\%) it will cause a reduction of $(1.42 \%)$ in EG or GDP on short-term and the opposite on the long-term model. CointEq1 or error correction model results revealed that economic growth or GDP needs a long time to return to its stability value in the long run, which is estimated at $(-10.66 \%)$ annually and is considered very low. In other words, the economic growth needs about ten years to reach a full long run adjustment.

\section{Table 6}

Short-Term Estimates

\begin{tabular}{lccc}
\hline Variables & Coefficient & T-statistics & \\
\hline CointEq1 & -0.106610 & -3.82376 & \\
DG(-1) & -1.223569 & -2.02897 & \\
DF(-1) & -0.014242 & -1.08626 & 0.02788 \\
DP(-1) & 1.187116 & 1.59149 & 0.6030 \\
C & 0.068006 & 4.48640 & 0.01311 \\
\hline
\end{tabular}

Source: Authors calculation with using E-Views 10

\subsection{Structural stability}

The last step of empirical analysis is study variables' stability which done by using both CUSUM and CUSUMSQ tests, where graphs $(2 \& 3)$ reveal that estimated coefficients of the ARDL model structural stability over the study period confirm stability of variables in the study model thru short and long-term Error Correction results, and two tests of this model were within critical limits at a significance level of $(5 \%)$.

\section{Results and conclusion}

Research presents additional evidence on the Nexus FPI-Economic Growth to support literature review, and aims to test FPI impact on Jordan EG thru (1996-2017). Research used various techniques to determine this impact, such as ARDL Model, Errors Correction Model, and Structural Stability. Results showed FPI in Jordan divided into three periods; the first one reveals that FPI moved at slightly higher stability during this period, while the second period indicated a gradual and noticeable increase in FPI, but the last period showed that FPI witnessed a rapid decline due to the impact of global financial crises. The 
experimental results revealed that FPI have a long-term significant positive effect on Jordan's EG by using ARDL model, which confirms the significance of foreign investments on enhancing EG rates through overcoming legal legislations, as well as developing the infrastructure of Amman Financial Market which encourage foreign investors to transfer their funds to financial investment securities. In the short-term, FPI will have insignificant impact on EG by implementing Error Correction Model.

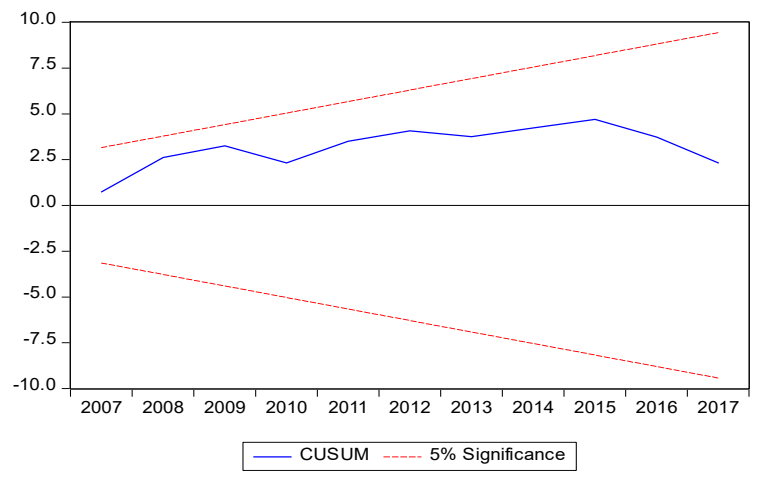

Fig. 2 Plot of CUSUM Test

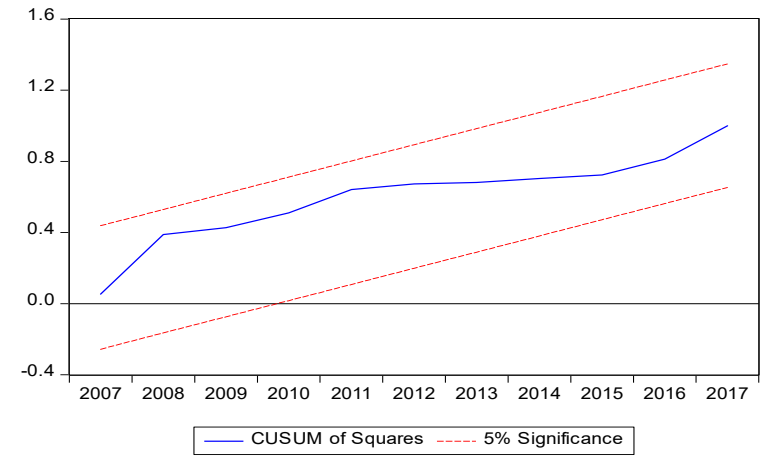

Fig. 3 Plot of CUSUMQ Test

\section{References}

Agarwal, R. N. (1997). Foreign portfolio investment in some developing countries: A study of determinants and macroeconomic impact. Indian Economic Review, 32(2), 217-229.

Ahmad, F., Draz, M. U., \& Yang, S. C. (2016). Foreign portfolio inflows and economic growth: Evidence from ASEAN5. Actual Problems of Economics, 179(5), 57-69.

Albulescu, C. T. (2015). Do Foreign Direct and Portfolio Investments Affect Long-term Economic Growth in Central and Eastern Europe?. Procedia Economics and Finance, 23, 507-512.

Baghebo, M., \& Apere, T. (2014). Foreign portfolio investment and economic growth in Nigeria (1986-2011). International Journal of Business and Social Science, 5(11), 108-115.

Baharumshah, A. Z., \& Thanoon, M. A. M. (2006). Foreign capital flows and economic growth in East Asian countries. China Economic Review, 17(1), 70-83.

Brown, R. L., Durbin, J., \& Evans, J. M. (1975). Techniques for testing the constancy of regression relationships over time. Journal of the Royal Statistical Society: Series B (Methodological), 37(2), 149-163.

Cobb, C. W., \& Douglas, P. H. (1928). A theory of production. The American Economic Review, 18(1), 139-165.

Duasa, J.P., \& Kassim, S.H. (2009). Foreign Portfolio Investment and Economic Growth in Malaysia. The Pakistan Development Review, 48( 2), 109-123

Durham, J.P. (2003). Absorptive capacity andthe effects of foreign direct investment and equity foreign portfolio investment on economic growth. European Economic Review, 48(2), 285-306

Elliott, G., Rothenberg, T. J., \& Stock, J. H. (1992). Efficient tests for an autoregressive unit root (No. t0130). National Bureau of Economic Research, 64(4), 813-836

Garg, R., \& Dua, P. (2014). Foreign portfolio investment flows to India: determinants and analysis. World development, 59, 16-28.

Goldstein, I., \& Razin, A. (2006). An information-based trade off between foreign direct investment and foreign portfolio investment. Journal of International Economics, 70(1), 271-295.

Granger, C. W. J (1969). Investigating Causal Relations by Econometric Models and Cross-spectral Methods. Econometrica, 37(3), 424-438.

Johansen, S. (1991). Estimation and Hypothesis Testing of Cointegration Vectors in Gaussian Vector Autoregressive Models. Econometrica, 59(6), 1551-1580.

Pesaran, M. H., \& Pesaran, B. (1997). Microfit 4.0: Interactive Econometric Analysis, Oxford University Press.

Philips, P.C.P., \& Perron, P. (1988). Testing for a unit root in time series regression. Biometrika, 75(2), 335-346.

Sawalha, N. N., Elian, M. I., \& Suliman, A. H. (2016). Foreign capital inflows and economic growth in developed and emerging economies: A comparative analysis. The Journal of Developing Areas, 50(1), 237-256.

Sethi, N., \& Patnaik, K. U. S. (2007). Impact of international capital flows on India's Economic Growth. The ICFAI Journal of Applied Finance, 13(1), 89-96.

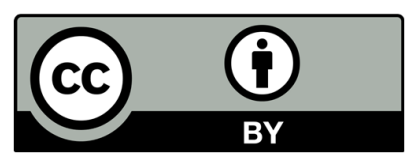

(C) 2021 by the authors; licensee Growing Science, Canada. This is an open access article distributed under the terms and conditions of the Creative Commons Attribution (CC-BY) license (http://creativecommons.org/licenses/by/4.0/). 